\title{
A new glacier inventory of Iran
}

\author{
M.S. MOUSSAVI, M.J. VALADAN ZOEJ, F. VAZIRI, M.R. SAHEBI, Y. REZAEI \\ Remote Sensing Department, K.N. Toosi University of Technology, Tehran, Iran \\ E-mail: ms.moussavi@gmail.com
}

\begin{abstract}
A new glacier inventory of Iran, compiled according to GLIMS guidelines through the use of photogrammetry and remote sensing supported by fieldwork, provides the first comprehensive study of its mountain glaciers. The glaciers are found in five main areas: two in the higher elevations of the Alborz mountain range (Damavand and Takhte-Soleiman regions), two on the Zardkuh and Oshtorankuh mountain chain in the Zagros mountain range and one in the Sabalan Mountains in northwest Iran. Several important glacier attributes, including minimum and maximum height of ice, area and maximum length and width, together with glacier extent, were successfully extracted using aerial and satellite imagery. Thereafter a comprehensive glacier database was established in a GIS environment.
\end{abstract}

\section{INTRODUCTION}

Glacier changes are key indicators for ongoing global climate change. They influence hydrologic regimes and may trigger natural hazards. In addition, they are unique sources of fresh water and an important economic factor for hydropower production (Paul, 2003).

In recent decades, a spectacular retreat has been observed on most of the monitored glaciers in the world. If this evolution is confirmed in coming years, it will have important consequences in terms of water resources, economic development and risk management in the surrounding areas. Up to now, only a few of the world's mountain glaciers have been monitored, mostly by ground measurements, which often provide information only once or twice a year at a few points (Trouvé and others, 2007).

Due to the difficulty of reaching high-altitude glaciers in risky mountainous areas, even with the advent of the differential global positioning system (DGPS) it remains difficult and time-consuming to perform regular groundbased surveys of glaciers (Berthier and others, 2005). The acquisition and processing of remotely sensed data should provide more information and improve glacier monitoring.

The use of satellite data for updating or generating glacier inventories has been discussed for many years. Furthermore, the combined use of satellite imagery and digital elevation models (DEMs) in a Geographic Information System (GIS) environment is a valuable method of efficient operational data processing (Paul, 2003).

In Iran, monitoring glaciers is especially important, since they supply a considerable portion of the drinking water. Glaciers in Iran are found in five main areas (Fig. 1): two are located in the higher elevations of the Alborz mountain range in northern Iran (one in the vicinity of TakhteSoleiman and the other on Mount Damavand); the others are found on the Sabalan Mountains in northwestern Iran, and on the Zardkuh and Oshtorankuh Mountains in the Zagros mountain range of southwestern Iran.

Based on the geological structure of the underlying bedrock of the glaciers, we divided Iran's glaciers into two categories: (1) granite glaciers and (2) karstic glaciers. These two types of glaciers have different glacial features (e.g. the thickness of ice in karstic glaciers is less than that of granite glaciers). Moreover, special features such as crevasses and moraines are not found on karstic glaciers, whereas sinkholes are observed on their surface. The glaciers in TakhteSoleiman and Sabalan regions and around Damavand summit have the granitic structure, whereas Oshtorankuh and Zardkuh glaciers are karstic.

Unfortunately, the glaciers in Iran were not thoroughly investigated until recently. The little work that was conducted by Europeans and Iranians was mostly ground-based (Ferrigno, 1991).

Here we present the results of the very first glacier inventory in Iran through the use of photogrammetry and remote sensing. Several important glaciers attributes including minimum and maximum height of ice, area and maximum length and width, along with glacier extent, have been successfully extracted using aerial and satellite imagery. These results have also been verified by extensive fieldwork. A comprehensive glacier database was established in a GIS environment, with respect to attributes defined in the Global Land Ice Measurements from Space (GLIMS) project.

\section{DATA}

\section{Aerial and satellite image data}

Airborne photography has been a major source of information on glaciers, as it is able to provide high-resolution data for the computation of high-resolution digital terrain models (DTMs) and orthoimages with accurate positions, obtained using GPS control points. However, due to the high cost of each campaign, few aerial photographs are available, which leads us to make use of another important source of information, that acquired by optical sensors on remotesensing satellites. Multitemporal satellite imagery, with its increasing resolution, large spatial coverage and spectral information, can be used to identify specific glacial features for change detection and risk assessment.

In this work, a variety of satellite images (Table 1) acquired by different sensors, along with aerial photographs, were utilized to compile the Iran Glacier Inventory (IGI).

\section{Data pre-processing}

In the pre-processing stage, selection of the most suitable satellite scenes, as well as geometric correction, were the most important tasks. For data selection, some limitations existed in terms of cloud cover at high altitudes and snow 
Table 1. Optical satellite imagery used in the Iran Glacier Inventory 2008. ETM+: Enhanced Thematic Mapper Plus; IRS: Indian Remotesensing Satellite; SPOT: Système Probatoire pour l'Observation de la Terre; ASTER: Advanced Spaceborne Thermal Emission and Reflection Radiometer

\begin{tabular}{lcc}
\hline Satellite image & Date & Glacier region \\
\hline QuickBird (panchromatic) & September 2005 & Takhte-Soleiman \\
QuickBird (multispectral) & September 2005 & Takhte-Soleiman \\
Landsat ETM+ & September 2002 & Damavand \\
Landsat ETM+ & September 2002 & Takhte-Soleiman \\
IRS P5 (panchromatic) & September 2007 & Takhte-Soleiman \\
SPOT5 (panchromatic) & September 2004 & Takhte-Soleiman \\
ASTER & August 2001 & Oshtorankuh \\
ASTER & August 2001 & Zardkuh \\
IRS (panchromatic) & September 2003 & Zardkuh
\end{tabular}

cover, which had to be taken into consideration. Hence, images acquired at the end of the ablation period, around September, were chosen. Having selected suitable satellite imagery (level 1 data that had already been radiometrically corrected), geometric correction and georeferencing of images were carried out.

\section{DEM generation}

Several series of aerial photographs at scales of $1: 40000$ and 1:50000 were selected over the five glacier zones in Iran. These photographs were provided by Iran's National Cartographic Center. The $\sim 23 \mathrm{~cm} \times 23 \mathrm{~cm}$ negatives were scanned at a resolution of $14 \mu \mathrm{m}$.
Firstly, the digital images were oriented through photogrammetric processing. The required ground-control points (GCPs) were acquired using the 'bundle-block aerial triangulation' technique, which enables global restitution of a block of photographs and reduction of GCPs. Bundleblock adjustment is an iterative method based on the use of photographic coordinates as observations. Application of the central projection method enables the conversion of these observations into terrain coordinates in one step (Trouvé and others, 2007). This requires a block of photographs with at least $60 \%$ overlap and $20 \%$ side-lap (often there is more) (Trouvé and others, 2007). Moreover, sets of GPS points located on both sides of the glaciers in different study areas were required for the orientation process. The number of points used in each study area varied, depending on data availability. The matching procedure was carried out both automatically and manually. Wherever automatic correlation was problematic, due to factors such as snow-cover conditions or poor contrast, stereoscopic measurement was required. Eventually, DEMs and ortho-photographs of glacier zones were produced using Virtozou NT photogrammetric software. Later, orthoimage mosaics of the glacier areas were also generated.

\section{GLACIER INVENTORY}

Iran's glaciers have been the subject of many studies by several European and Iranian researchers since 1933 (e.g. Busk, 1933; Desio, 1934; Bobek, 1937; Harding, 1957; Péguy, 1959; Schweizer, 1970; Troll, 1973; Grunert and others, 1978; Ferrigno, 1991; Rezaei, 2003; Vaziri, 2003)

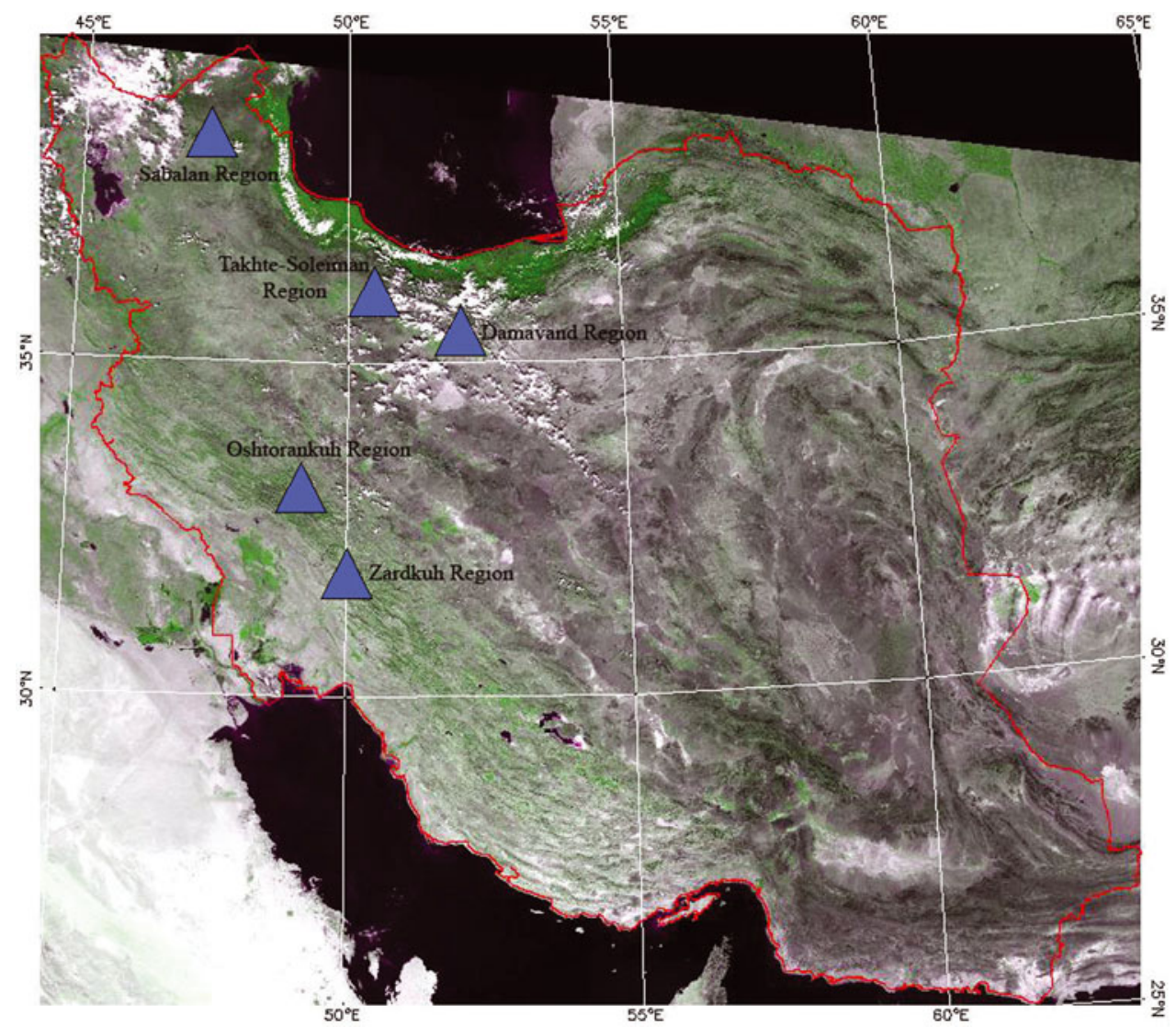

Fig. 1. Glacier regions in Iran (MODIS (moderate-resolution imaging spectroradiometer) image). 
However, none of these represent a comprehensive inventory of the glaciers and their characteristics; for instance, one glacier region (Oshtorankuh) was not identified at all. Moreover, there was no accurate information on the total areal coverage of glaciers in Iran. A rough estimate was made to be $20 \mathrm{~km}^{2}$ (Ferrigno, 1991), based on estimates of $14 \mathrm{~km}^{2}$ for the glaciers of the Takhte-Soleiman region and 2, 2.4 and $1.5 \mathrm{~km}^{2}$ for Damavand, Sabalan and Zardkuh regions, respectively.

In this study, initially five main glacier regions in Iran were identified through the use of aerial and satellite imagery and extensive fieldwork (Fig. 1). The fieldwork was carried out by F. Vaziri, who has been studying the glaciers since 1983. His work (Vaziri, 2003) remains the most valid reference on Iran's glaciers at present.

In this inventory, the current size of Iran's glaciers is estimated to be $27 \mathrm{~km}^{2}$. It is found that the glaciers in the Takhte-Soleiman region occupy a total area of $7.55 \mathrm{~km}^{2}$, and glaciers in Damavand, Sabalan, Zardkuh and Oshtorankuh regions occupy areas of $3.4,4.27,7.1$ and $4.8 \mathrm{~km}^{2}$, respectively.

Related physical attributes were calculated through image-processing techniques, and the results were validated by ground survey. In the following we present a thorough description of each glacier region, along with its extracted attributes.

\section{Takhte-Soleiman region}

The largest glaciers in Iran exist in the western part of the Alborz mountain range, in the region of the TakhteSoleiman massif $\left(36^{\circ} 22^{\prime} \mathrm{N}, 50^{\circ} 57^{\prime} \mathrm{E}\right)$. The highest peak of this region, Alamkuh (4850 ma.s.l.), is the second highest peak in Iran. The region consists of 45 peaks $>4000 \mathrm{~m}$ in elevation that are joined by high, narrow summit ridges. The glaciers are found mostly on the steep, northward-facing slopes of these peaks and ridges (Vaziri, 2003).

In this inventory, the glaciers in Takhte-Soleiman region were comprehensively studied through the use of aerial and satellite imagery. The largest glacier was found to occupy an area of $\sim 3.3 \mathrm{~km}^{2}$. It is called Northern Glacier, previously known to researchers as Sarchal Glacier. It is formed from the confluence of three unequal segments (Fig. 2). The surface of the glacier tongue is covered with debris $0.5-1.5 \mathrm{~m}$ thick. According to Vaziri, each of these segments is considered to be a glacier, and 1, 2, 3 in Figure 3 were named Alamchal, Patakht and Takhte-Soleiman, respectively. The height of the snowline is estimated to be $\sim 4000-4150 \mathrm{~m}$. The thickness of ice on this glacier varies from $50 \mathrm{~m}$ in the lower part of the

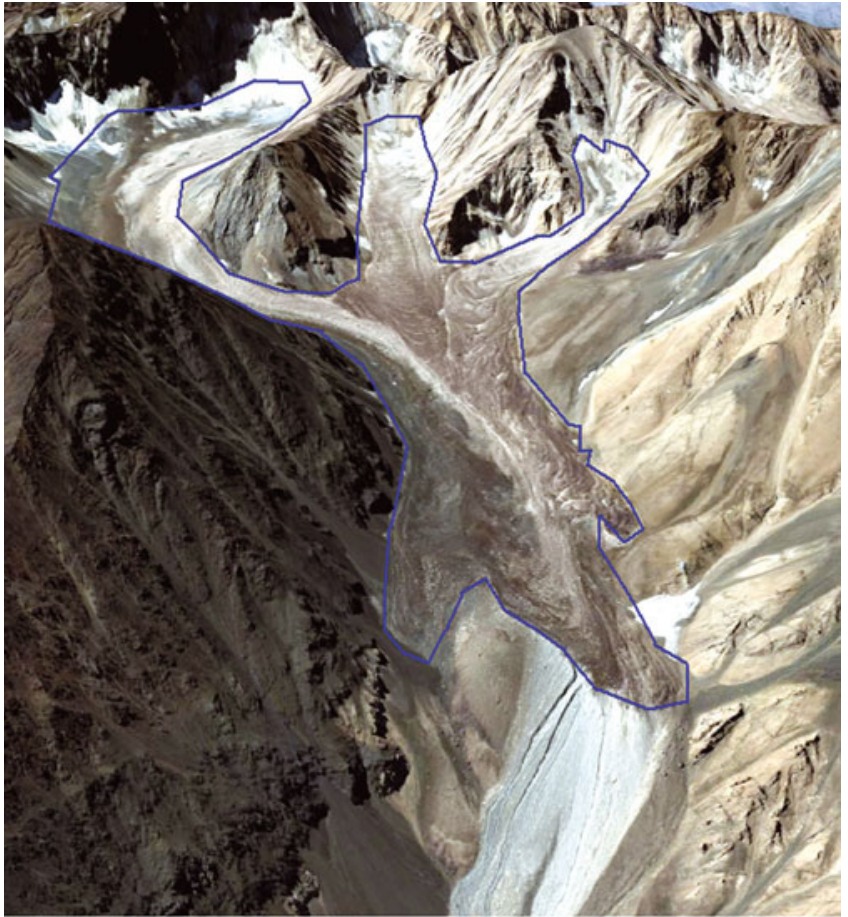

Fig. 2. Three-dimensional visualization of Northern Glacier with its digitized outline (QuickBird image 2005). (Takhte-Soleiman region.)

glacier to $80 \mathrm{~m}$ on the cirque (Fig. 4a) (Vaziri, 2003). Several crevasses are observed on the surface of this glacier (Fig. 4b).

In Figure 3, four other mountain glaciers can be noted in the Takhte-Soleiman region: Haft-Khan, Merjikesh, Khersan and Western Glaciers.

The DEM of this region was used to obtain threedimensional (3-D) glacier attributes, such as minimum and maximum height of ice occurrence. Glacier area was provided within the GIS automatically for each glacier, and glacier length was obtained from digitized central flowlines. Further 3-D parameters (e.g. slope and aspect) were obtained from DEM-derived products.

Two 3-D DEM parameters are displayed in Figure 5 for the Takhte-Soleiman region. In Figure $5 a$, grey shades from black to white denote slope from high to low values. A mean slope for each glacier is also provided in Table 2. The aspect values in Figure $5 \mathrm{~b}$ are coded as eight grey levels, representing eight aspect sectors.

In Table 2 a list of the glaciers in the Takhte-Soleiman region, along with their physical attributes extracted from

Table 2. Physical attributes of glaciers in Takhte-Soleiman region

\begin{tabular}{|c|c|c|c|c|c|c|c|c|}
\hline Glacier & & Orientation & $\begin{array}{c}\text { Minimum height } \\
\mathrm{m}\end{array}$ & $\begin{array}{c}\text { Maximum height } \\
\mathrm{m}\end{array}$ & $\begin{array}{l}\text { Area } \\
\mathrm{km}^{2}\end{array}$ & $\begin{array}{l}\text { Maximum length } \\
\mathrm{km}\end{array}$ & $\begin{array}{l}\text { Maximum width } \\
\text { km }\end{array}$ & Mean slope \\
\hline \multirow[t]{3}{*}{ Northern } & Alamchal & Northeast & 3630 & 4360 & 2.27 & 4.3 & 1.32 & 12.79 \\
\hline & Patakht & Northeast & 3850 & 4130 & 0.47 & 1.9 & 0.36 & 13.27 \\
\hline & Takhte-Soleiman & Northeast & 3740 & 4220 & 0.56 & 1.6 & 0.25 & 15.19 \\
\hline Western & & Northwest & 3900 & 4330 & 0.46 & 1.7 & 0.47 & 21.33 \\
\hline Haft-Khan & & North & 3740 & 4250 & 2.52 & 3.06 & 0.4 & 20.06 \\
\hline Khersan & & Southeast & 4065 & 4425 & 0.54 & 2 & 0.24 & 16.93 \\
\hline Merjikesh & & Southeast & 4070 & 4460 & 0.73 & 1.37 & 0.22 & 21.89 \\
\hline
\end{tabular}




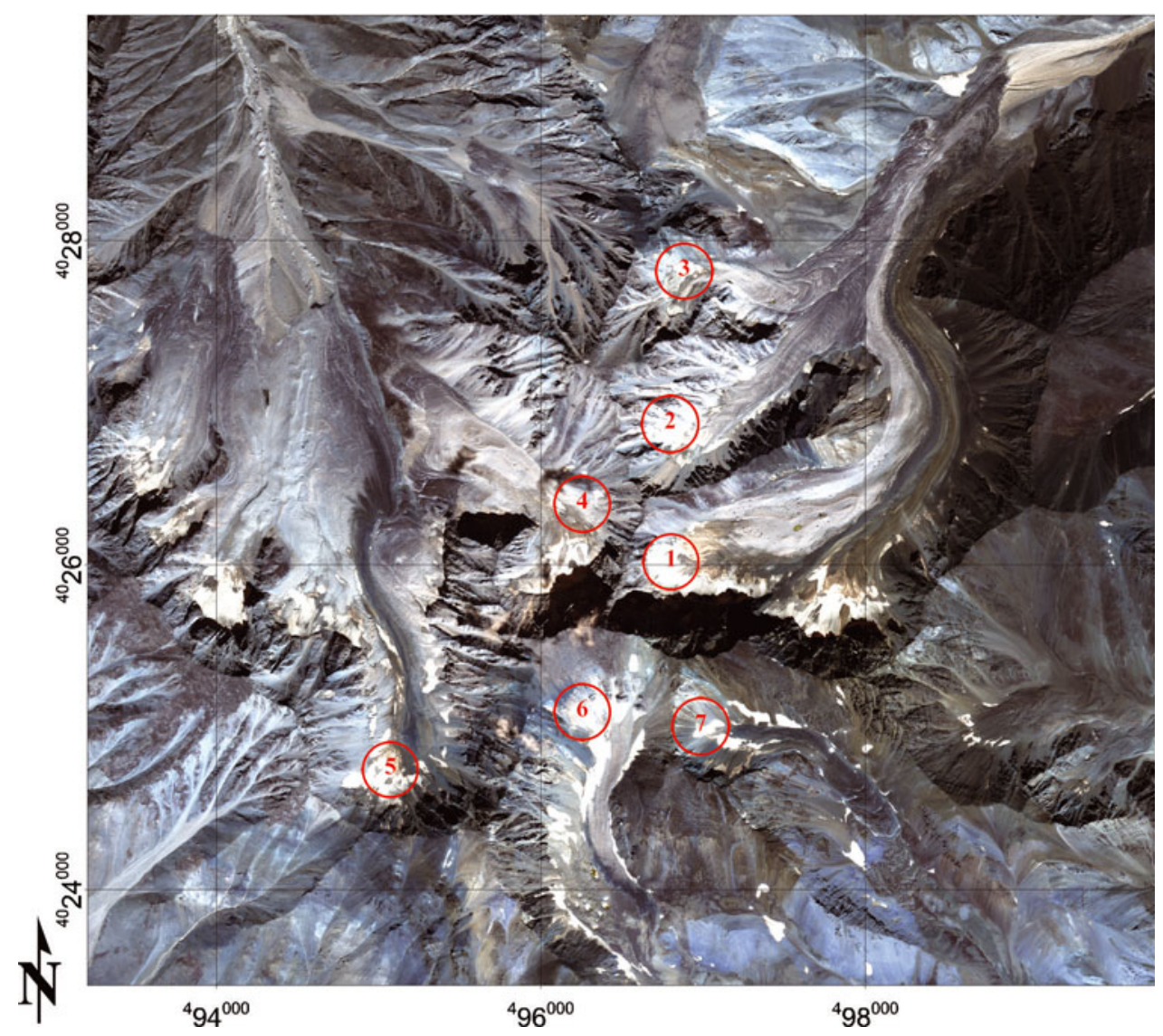

Fig. 3. QuickBird image of the Takhte-Soleiman region. 1. Alamchal Glacier; 2. Patakht Glacier; 3. Takhte-Soleiman Glacier; 4. Western Glacier; 5. Haft-Khan Glacier; 6. Khersan Glacier; 7. Merjikesh Glacier.

2005 QuickBird panchromatic imagery (spatial resolution $0.6 \mathrm{~m})$ and the DEM, are presented. Two close-range photographs of the glaciers in the Takhte-Soleiman region are shown in Figure 4.

\section{Sabalan region}

This glacier region lies in the northwestern part of the country and is located $85 \mathrm{~km}$ from the city of Ardebil in eastern Azerbaijan province. The area has a continental climate with hot, relatively dry summers and extremely cold, snowy winters. The precipitation, which falls almost exclusively as snow in the late autumn, winter and spring, nourishes the glaciers on the highest peaks; however, during the arid summer, there is considerable ablation (Schweizer, 1970). The height of the snowline is estimated to be $4000 \mathrm{~m}$. The highest peak in this region, Mount Sabalan $\left(38^{\circ} 16^{\prime} \mathrm{N}\right.$, $47^{\circ} 50^{\prime} \mathrm{E}$ ), is an inactive stratovolcano that rises to a height of 4811 ma.s.l. (Vaziri, 2003). It has a permanent crater lake formed at its summit, which is covered with ice from September through to June the next year. This freshwater lake occupies an area of $0.01 \mathrm{~km}^{2}$ and is $15 \mathrm{~m}$ deep.

The glaciers on Sabalan are often characterized by a thick, continuous debris cover, and many glaciers appear to grade into or continue as rock glaciers (Ferrigno, 1991). As can be

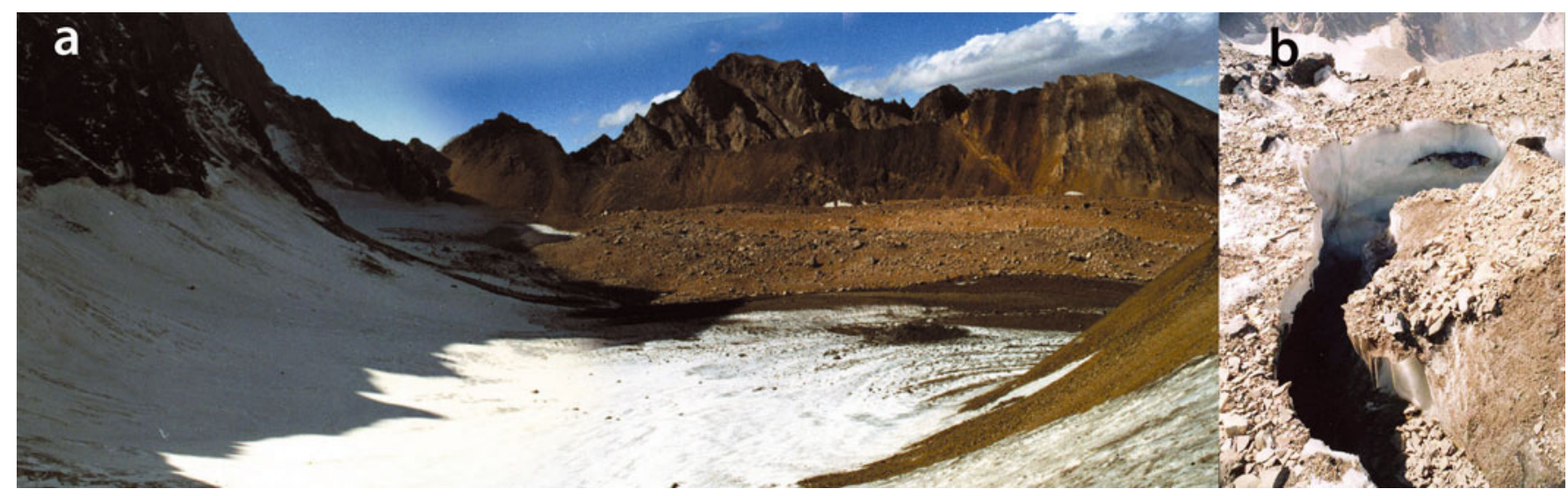

Fig. 4. Close-range photographs of Alamchal Glacier (October 1995): (a) the glacier's cirque; (b) a crevasse on the surface of the glacier. (Photographs taken by F. Vaziri.) 

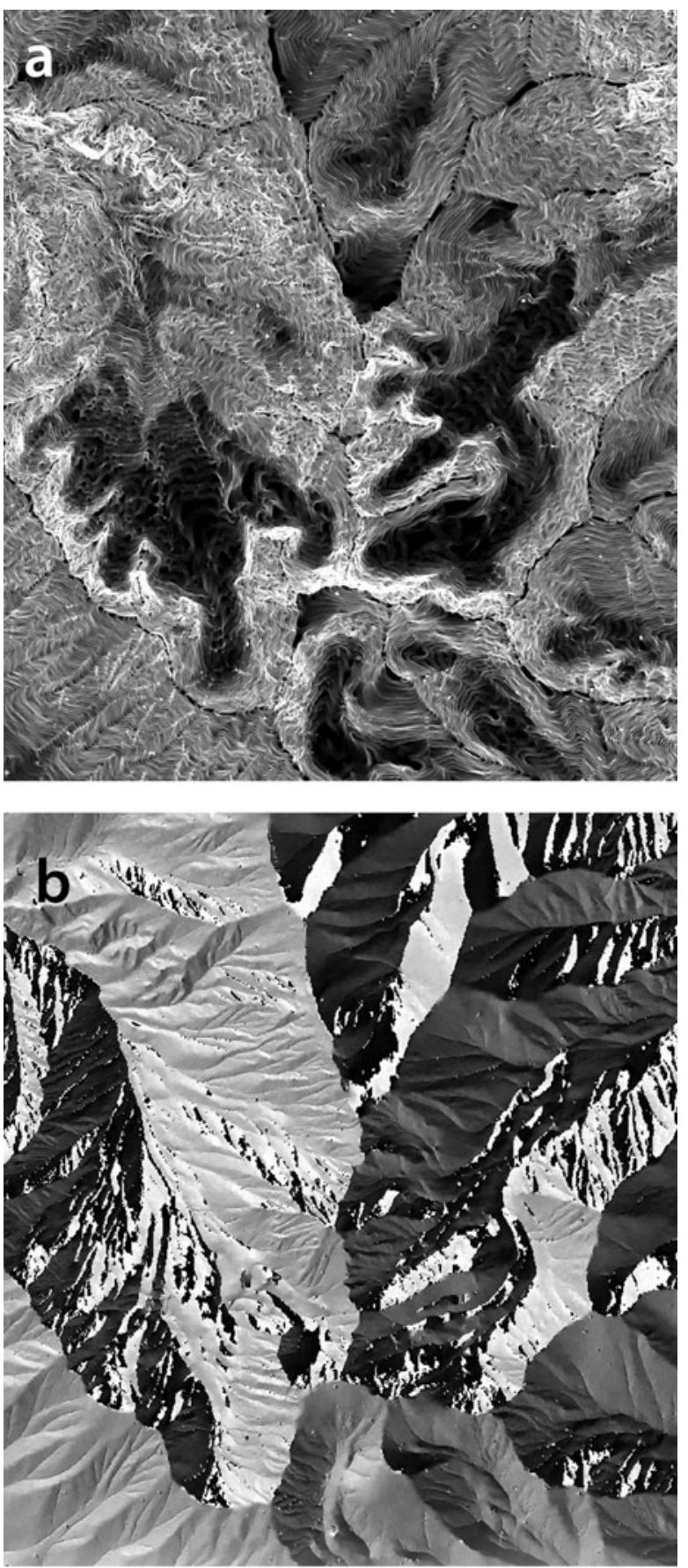

Fig. 5. Illustration of products from the DEM of the Takhte-Soleiman region: (a) slope, (b) aspect.

seen in Figure 6, penitents are found on the summit of Sabalan: they are an annual phenomenon of snow sublimation, related to solar radiation in an arid climate (Ferrigno, 1991). Although penitents form on the highest peaks in Iran, climate is more important than elevation to their formation. The incidence angle of the Sun, the intensity of the radiation, the dryness of the air in late summer and early autumn, and the time of maximum development, determine the occurrence, size and shape of the penitents (Ferrigno, 1991).

The main active glacier of this region, Northern Glacier (Fig. 7a), is a cirque glacier and includes three parts with special characteristics. The steep first part extends from the top of the glacier down to 4300 ma.s.l., where a large crevasse crosses the whole glacier. In the second part,

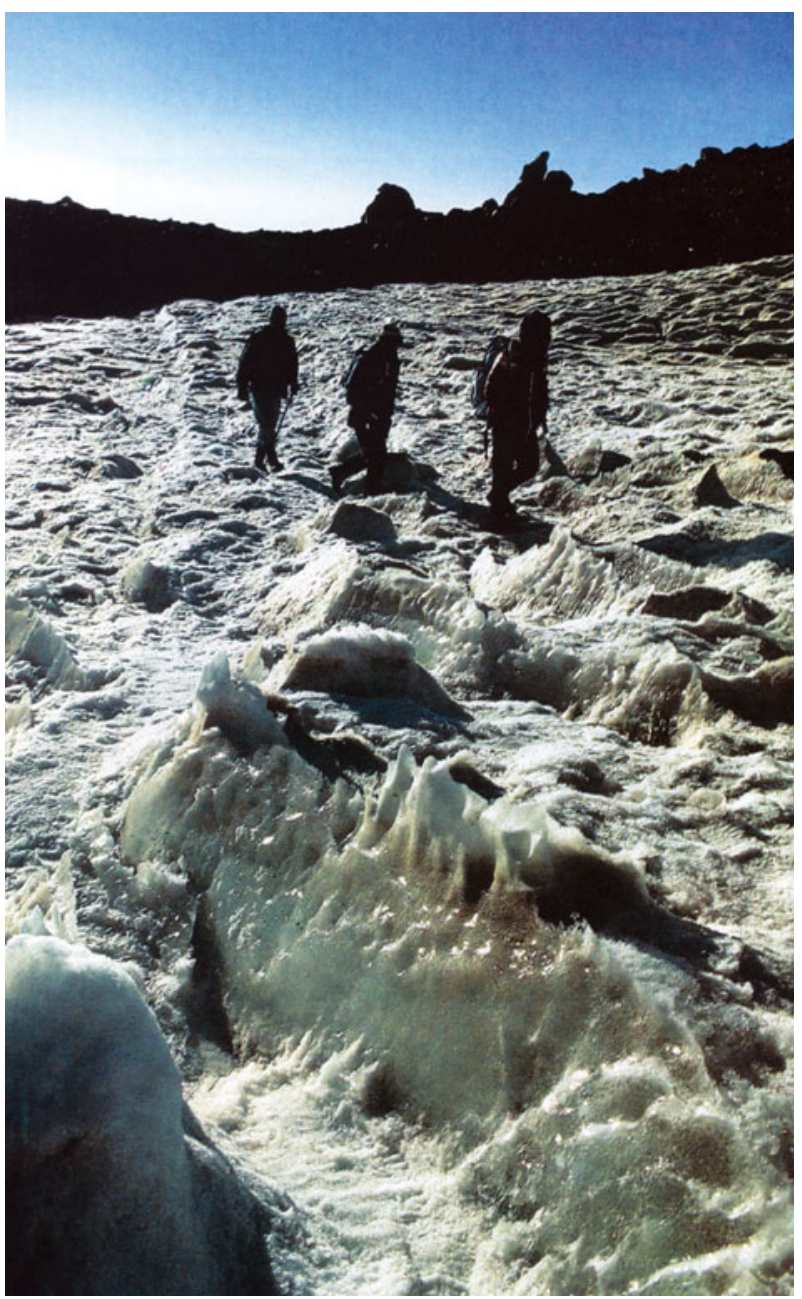

Fig. 6. Penitents on the summit of Mount Sabalan. (Photograph taken by F. Vaziri.)

spanning elevations from 4300 to 3900 ma.s.l., surface moraines of different sizes can be found, as well as linear crevasses in which water flows. The third part, continuing down to $3540 \mathrm{~m}$ in elevation, consists of coarse glacial sediments, including big cobblestones. In the northern part of Sabalan region, in Shirvan Valley, a big valley glacier exists which is a continuation of Northern Glacier. Five glaciers (Fig. 8) are identified in this region. Table 3 presents the related physical attributes, extracted from aerial photographs. Three rivers, namely, Anar-chai, Ghoori-chai and Darvish-chai, originate from the glaciers in the Sabalan region (Vaziri, 2003).

\section{Damavand region}

At present, all of the glaciers in the eastern Alborz mountain range are located on Damavand $\left(35^{\circ} 57^{\prime} \mathrm{N}, 52^{\circ} 06^{\prime} \mathrm{E}\right)$. Mount Damavand (5609 ma.s.I.), a dormant stratovolcano located $\sim 70 \mathrm{~km}$ northeast of Tehran, is the highest peak in Iran (Vaziri, 2003). The summit crater is $\sim 160 \mathrm{~m}$ wide and $20 \mathrm{~m}$ deep and has a small lake in it which is frozen most of the year.

Despite the low mean annual temperature and high level of precipitation in comparison with other glacial regions, due to the steep slope of the conical-shaped mountain and the heat induced by volcanic activities, glacial erosional features (e.g. glacial cirques) have not developed. However, 


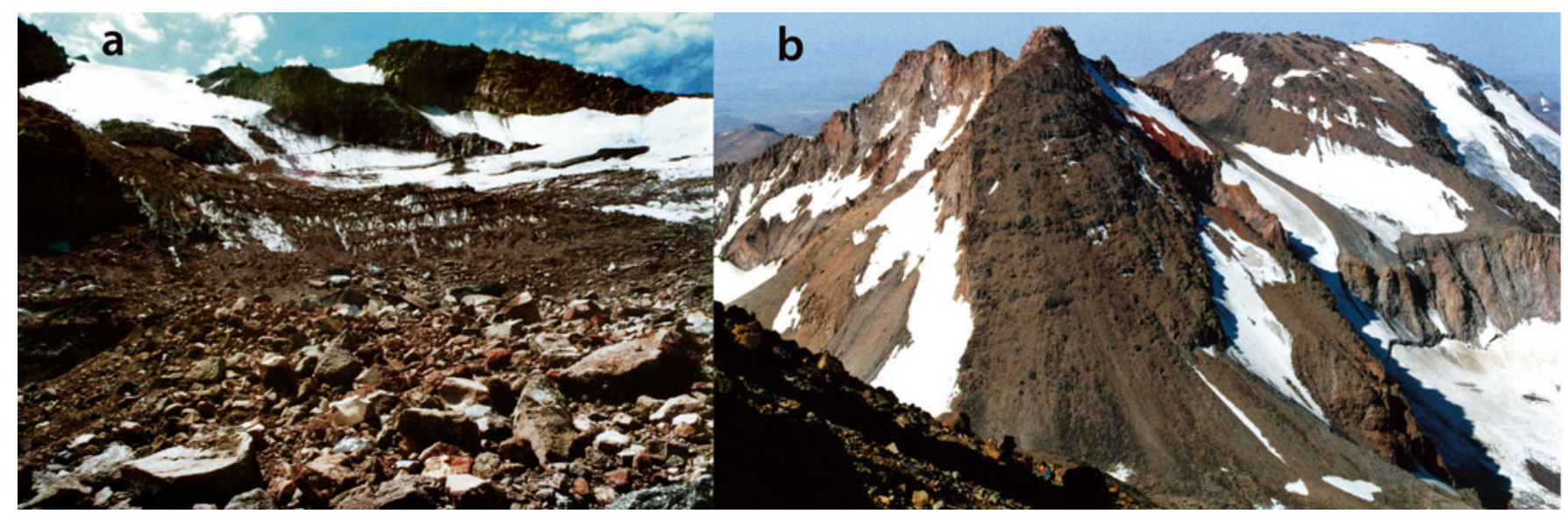

Fig. 7. Close-range photograph of Sabalan glaciers (July 1995). (a) Northern Glacier. (b) Glaciers around Herame-kasra summit: 1. Heramekasra Glacier; 2. Herame-kasra Southeastern Glacier; 3. Southern Glacier. (Photographs taken by. F. Vaziri.)

Table 3. Physical attributes of glaciers in Sabalan region

\begin{tabular}{|c|c|c|c|c|c|c|}
\hline Glacier & Orientation & $\begin{array}{l}\text { Minimum height } \\
\text { m }\end{array}$ & $\begin{array}{c}\text { Maximum height } \\
\mathrm{m}\end{array}$ & $\begin{array}{l}\text { Area } \\
\mathrm{km}^{2}\end{array}$ & $\begin{array}{c}\text { Maximum length } \\
\text { km }\end{array}$ & $\begin{array}{c}\text { Maximum width } \\
\text { km }\end{array}$ \\
\hline Northern & North & 3660 & 4765 & 0.82 & 1.7 & 0.63 \\
\hline Northwestern & Northwest & 3800 & 4550 & 0.62 & 2.1 & 0.3 \\
\hline Herame-kasra (Fig. 7b) & North & 3600 & 4460 & 0.93 & 2.9 & 0.5 \\
\hline Herame-kasra Southeastern (Fig. 7b) & Southeast & 4000 & 4300 & 0.3 & 1.25 & 0.12 \\
\hline Southern (Fig. 7b) & Southeast & 3700 & 4330 & 1.6 & 3.4 & 0.6 \\
\hline
\end{tabular}

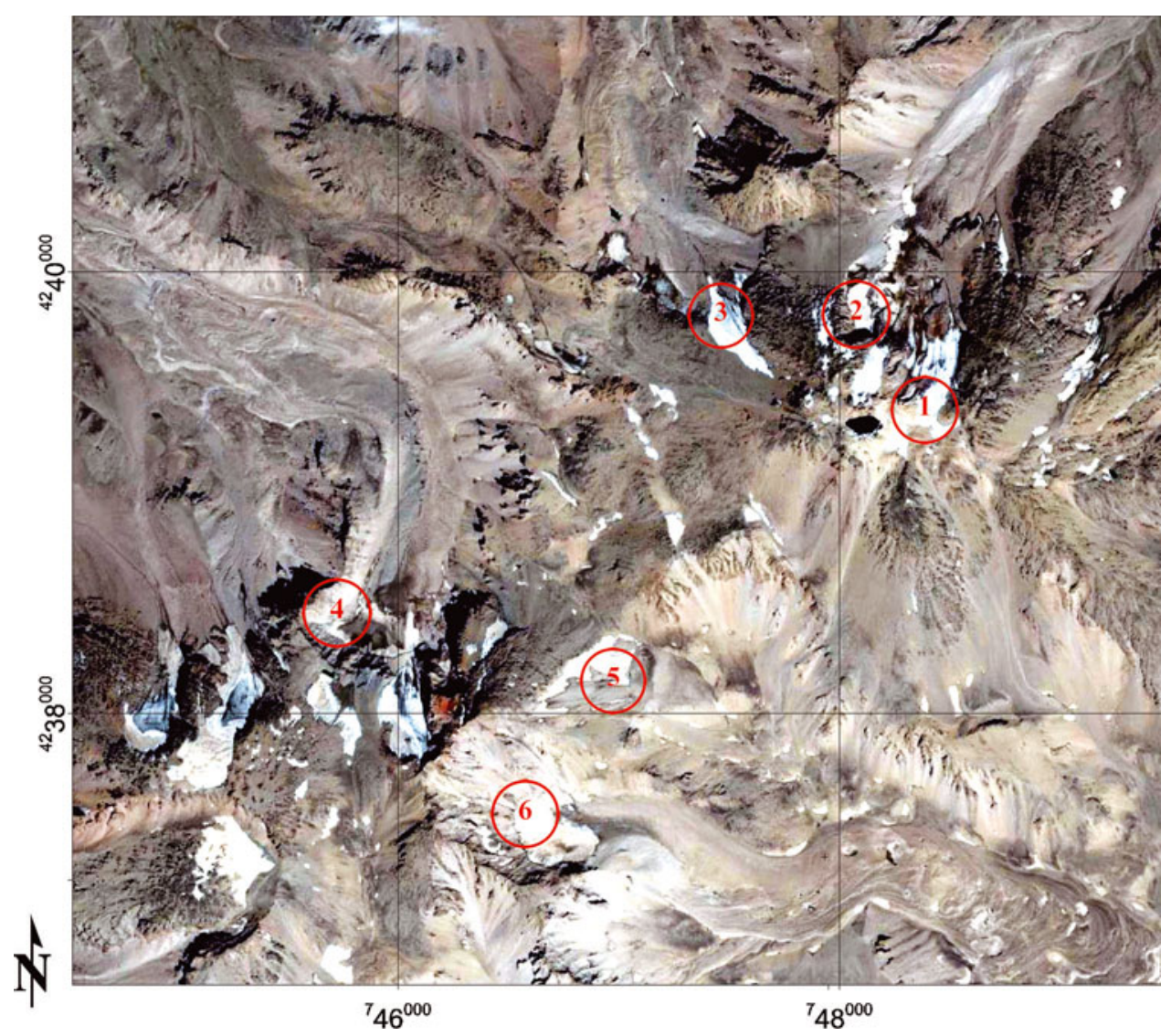

Fig. 8. QuickBird image of Sabalan region (Google Earth). 1. Sabalan summit crater; 2. Northern Glacier; 3. Northwestern Glacier; 4. Herame-kasra Glacier; 5. Herame-kasra Southeastern Glacier; 6. Southern Glacier. 


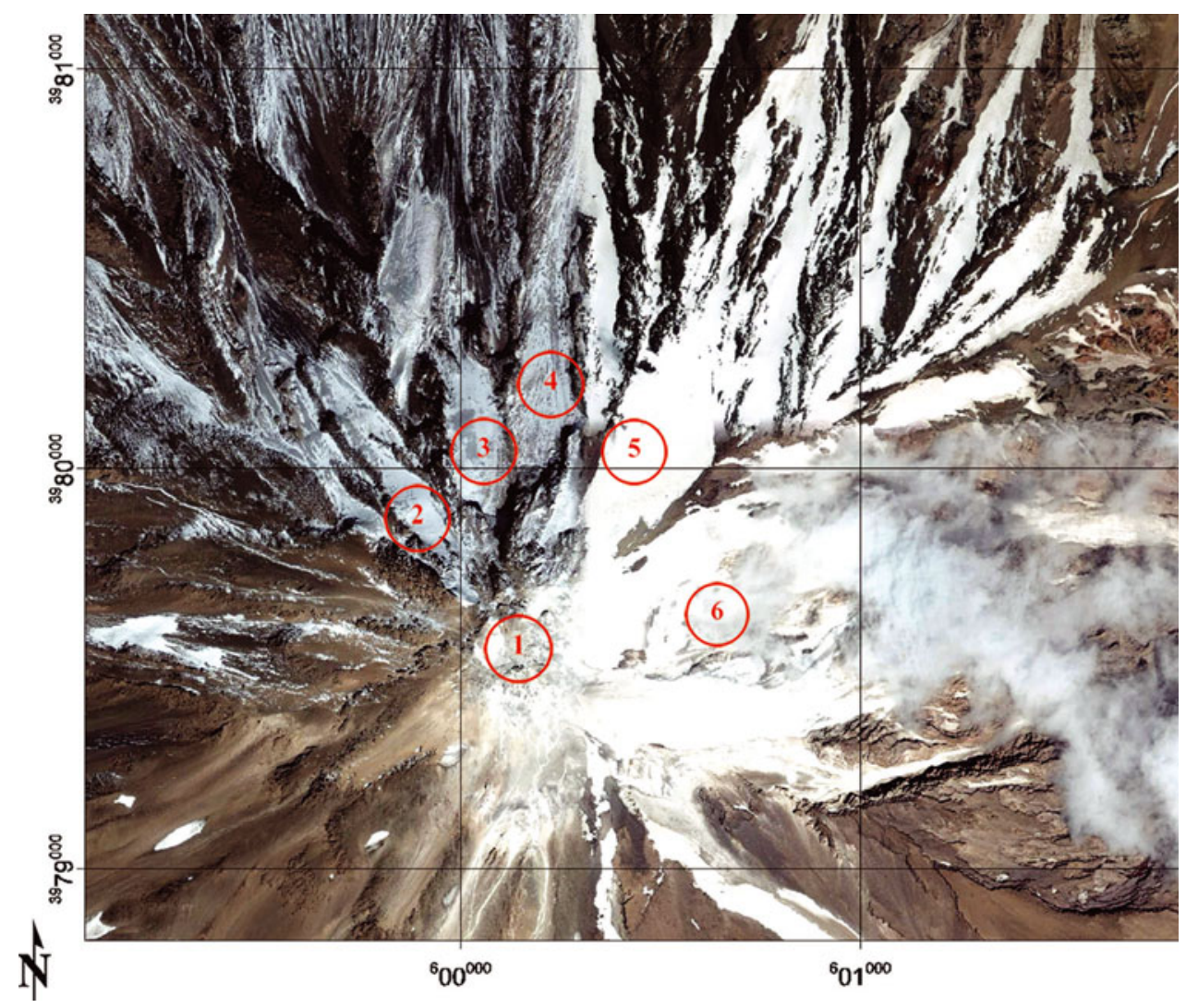

Fig. 9. QuickBird image of Mount Damavand (Google Earth). 1. Damavand summit crater; 2. Siuleh Glacier; 3. Dubi-sel Glacier; 4. Speleh Glacier; 5. Khurtabsar Glacier; 6. Yakhar Valley Glacier.

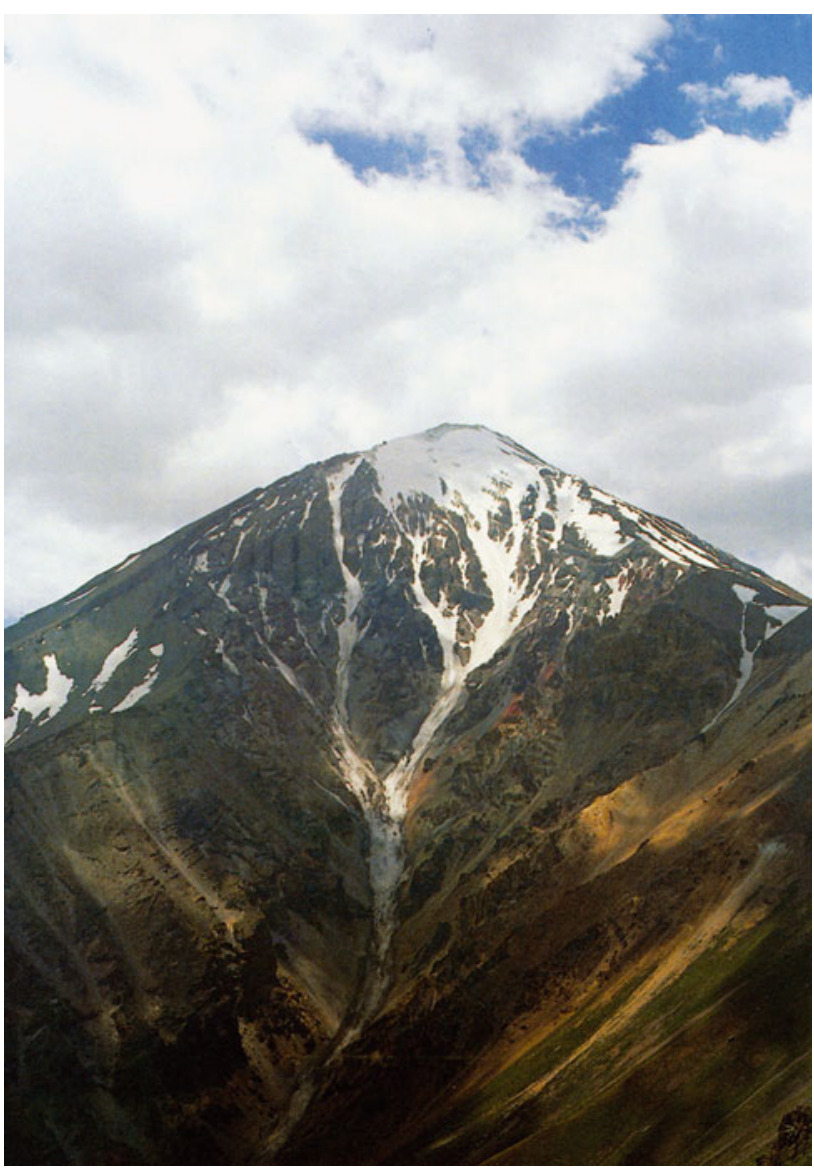

Fig. 10. Yakhar Valley Glacier (July 2003). (Photograph taken by F. Vaziri.) there are at least five main glaciers around Damavand summit which fall within the category of hanging glaciers (Fig. 9). There are four glaciers on the north face of Damavand, called Siuleh, Dubi-sel, Speleh and Khurtabsar. On the eastern side of Mount Damavand, in the massive Yakhar Valley, there is a large glacier, Yakhar Valley Glacier, which is the main source of Talkhrood River (Fig. 10). There are also several other glaciers on the south and southeast faces of Damavand which are relatively small, such as KafarDareh Valley Glacier and Sardagh Glacier. Some of Damavand's glaciers cannot qualify as permanent glaciers, since they may disappear during a hot, dry summer.

The average snowline in this region is $\sim 4400 \mathrm{~m}$ a.s.I. Due to the steep slopes of these glaciers, $26-40 \%$, the thickness of ice does not exceed $20 \mathrm{~m}$. The glaciers are covered with large penitents, $50-80 \mathrm{~cm}$ or more in height, and series of crevasses (Vaziri, 2003), though there is not much debris cover. Table 4 lists the main glaciers around Damavand summit, along with related glacial attributes.

\section{Oshtorankuh region}

In this glacier region, research was only conducted recently. Here we present the first results on the glaciers in the Oshtorankuh region.

Oshtorankuh region, with its highest peak, Sanboran summit, which rises to a height of $\sim 4050 \mathrm{~m}$ a.s.l., is located $33^{\circ} 20^{\prime} \mathrm{N}, 49^{\circ} 18^{\prime} \mathrm{E}, 38 \mathrm{~km}$ from Doroud city in Lorestan province. There are several glaciers in this region that are formed on the north- and northeast-facing slopes, since the prevailing winds from the south and the intense solar radiation prevent snow accumulation on south-facing slopes (Vaziri, 2003). These glaciers provide a high 


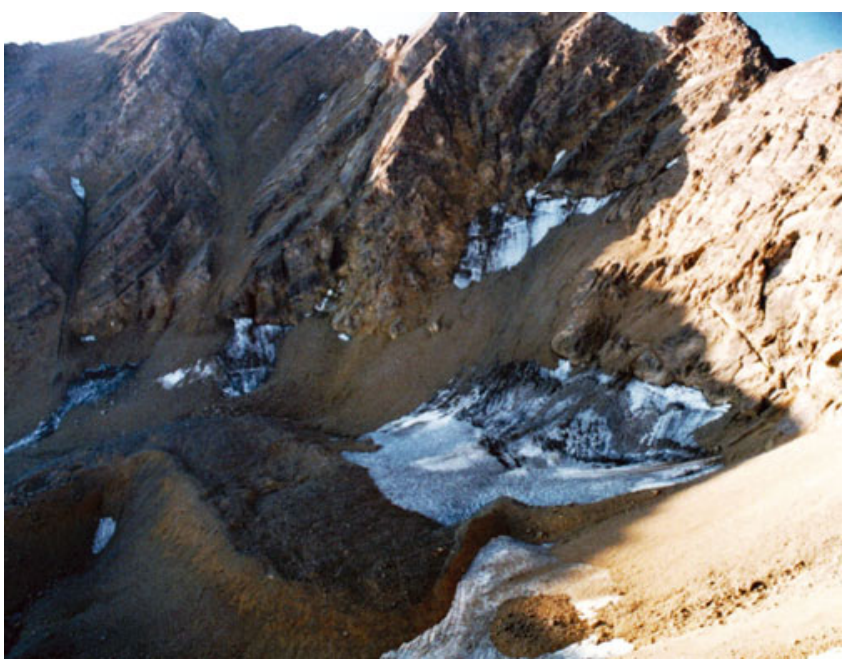

Fig. 11. Close-range photograph of Chal-kabud Glacier (July 1999). (Photograph taken by F. Vaziri.) percentage of the drinking water in the surrounding urban regions and are the origins of several rivers; for instance, Chal-mishan, Chal-kabud (Fig. 11) and Chal-boran glaciers are the main sources of the Ab-mishan, Alvand Valley and Mirzayi rivers (Vaziri, 2003).

Due to the karstic nature of the glaciers' bedrock, several sinkholes are observed on the surface of the glaciers (Vaziri, 2003). Mechanisms of formation may include the gradual dissolution of the bedrock, in this case limestone, by percolating snowmelt water. Generally, in karstic glaciers, the ice thickness is affected by water circulation, but it also depends on annual precipitation.

The glacial attributes of the glaciers in the Oshtorankuh region (Fig. 12) were initially extracted from Advanced Spaceborne Thermal Emission and Reflection Radiometer (ASTER) imagery, but they were updated by processing aerial photographs. The results were also verified by extensive fieldwork. A list of the glaciers and their attributes is presented in Table 5.

Table 4. Physical attributes of glaciers around Damavand summit

\begin{tabular}{|c|c|c|c|c|c|c|}
\hline Glacier & Orientation & $\begin{array}{l}\text { Minimum height } \\
\text { m }\end{array}$ & $\begin{array}{c}\text { Maximum height } \\
\text { m }\end{array}$ & $\begin{array}{l}\text { Area } \\
\mathrm{km}^{2}\end{array}$ & $\begin{array}{c}\text { Maximum length } \\
\text { km }\end{array}$ & $\begin{array}{c}\text { Maximum width } \\
\mathrm{m}\end{array}$ \\
\hline Siuleh & North & 4000 & 5400 & 1 & 2.2 & 600 \\
\hline Dubi-sel & North & 4100 & 5330 & 0.4 & 2 & 260 \\
\hline Speleh & North & 4050 & 5400 & 0.5 & 2 & 400 \\
\hline Khurtabsar & North & 3900 & 5070 & 0.5 & 1.7 & 300 \\
\hline Yakhar Valley & East & 4000 & 5600 & 1 & 1.7 & 600 \\
\hline
\end{tabular}

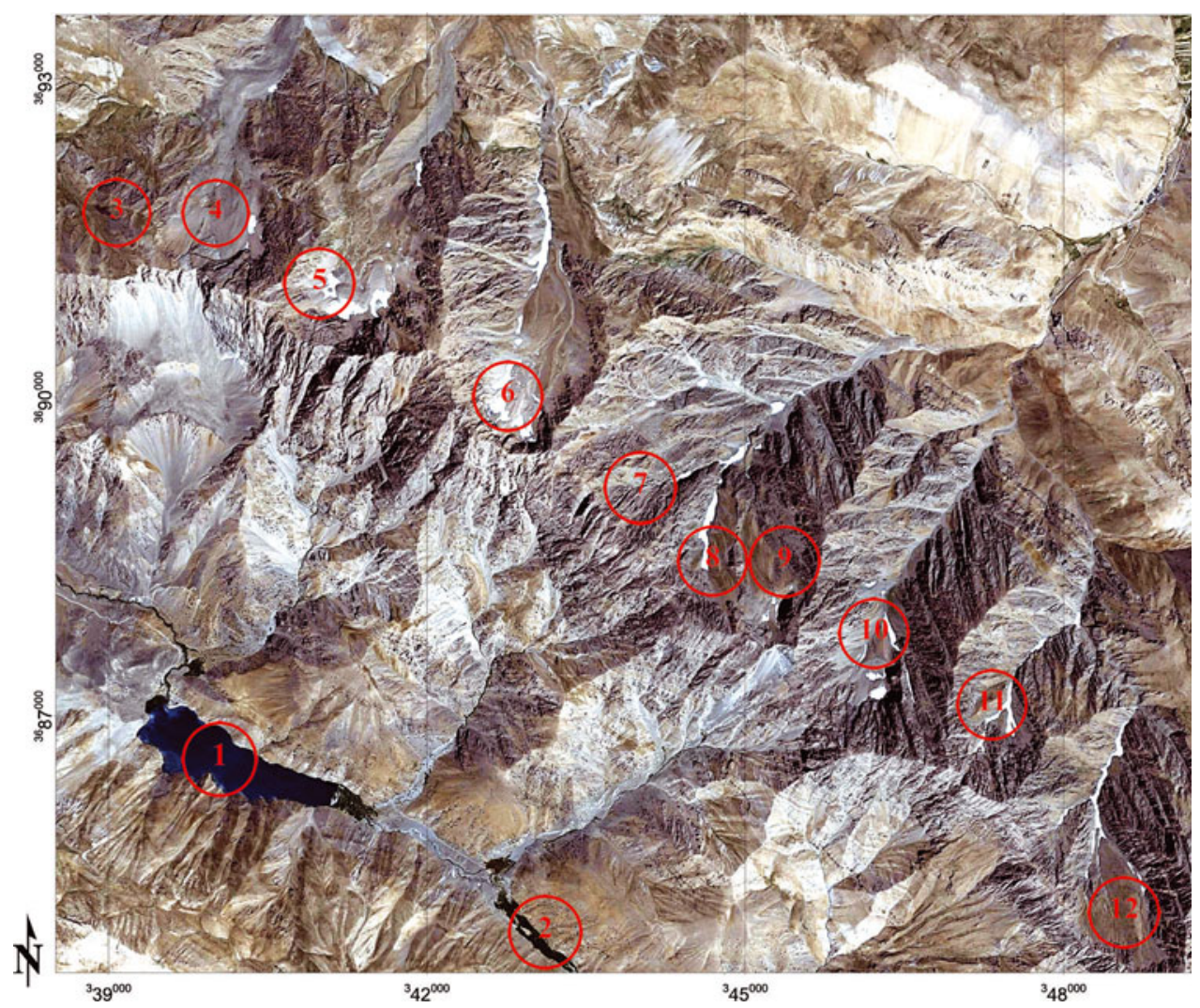

Fig. 12. SPOT image of Oshtorankuh region (Google Earth). 1. Big Gahar Lake; 2. Small Gahar Lake; 3. Kherseh dar Glacier; 4. Chal-mishan Glacier; 5. Chal-kabud Glacier; 6. Chal-boran Glacier; 7. Chal-fialeh-sun Glacier; 8. Shah-Takht Glacier; 9. Chal-piaro Glacier; 10. Chal-Homayun Glacier; 11. Chal-az-Nader Glacier; 12. Kul-Shakul Glacier. 


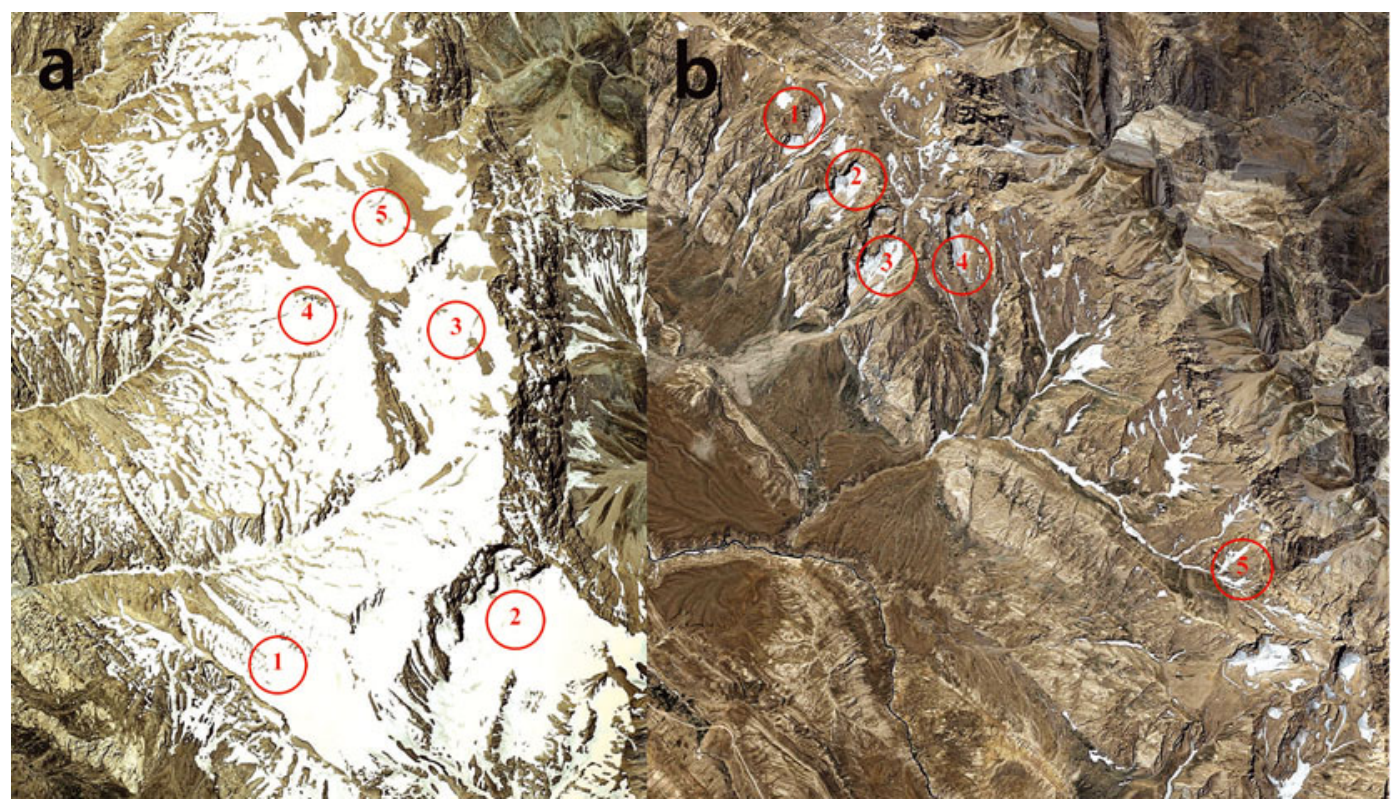

Fig. 13. SPOT image of Zardkuh region (Google Earth). (a) Glaciers around Joft-zarde and Zardkuh summits: 1. Chal-mishan Glacier; 2. Joftzarde Glacier; 3. Khersan Glacier; 4. Pursunan Glacier; 5. Zardkuh Southeastern Glacier. (b) Glaciers around Sirdan summit: 1. Kuhrang Glacier; 2. Kuhrang Glacier; 3. Kuhrang Glacier; 4. Kuhrang Glacier; 5. Haft-tanan (Iluk) Glacier. Note that north is down in these images.

\section{Zardkuh region}

The Zardkuh mountain chain lies along the central Zagros mountain range in the province of ChaharMahal-Bakhtiari. The highest peak of this mountain chain, Zardkuh (ShahShahidan) summit $\left(4548 \mathrm{~m}\right.$ a.s.l.) is located at $32^{\circ} 22^{\prime} \mathrm{N}$, $50^{\circ} 04^{\prime} \mathrm{E}$.

There are several glaciers in this region, mostly cirque glaciers, from which two well-known rivers, Kuhrang and Bazoft (Karun river branches), originate. The greatest glacier concentration in this region is observed in two main areas: (1) around Joft-zarde and Shah-Shahidan (Zardkuh) summits (Fig. 13a) and (2) around Sirdan summit (Fig. 13b) (Rezaei, 2003). Since the underlying bedrock of these glaciers is karstic, several sinkholes are observed on the surfaces of the glaciers (Fig. 14a and b).

The attributes of these glaciers were initially extracted from aerial photographs, Indian Remote-sensing Satellite (IRS) and ASTER imagery. The results are also supported by fieldwork. The list of the Zardkuh region glaciers and their attributes is presented in Table 6 .

\section{GIS database}

In this work we developed a GIS-based glacier database of Iran glaciers, carried out according to GLIMS standards. A GIS enables the automatic processing, integration, analysis and display of spatially oriented datasets (e.g. raster, vector, image), as well as storage and management of objectspecific attributes, making it a preferred tool for conducting glacier inventories (Paul, 2003). GISs can contribute significantly to the monitoring and investigation of glaciers, since all the data are georeferenced and, consequently, facilitate management and control procedures.

Obtaining glacier attributes for a large number of glaciers by traditional methods is laborious and prone to errors (Paul, 2003). The use of GIS technology offers four essential improvements: (1) storage of two-dimensional glacier outlines in a vector layer for tracing geometry changes; (2) storage of corresponding glacier attributes in a relational database; (3) combination with a DEM for retrieval of 3-D glacier attributes and topographic indices; and (4) programming allows fully automatic processing of all data (Paul, 2003).

Table 5. Physical attributes of glaciers in the Oshtorankuh region

\begin{tabular}{|c|c|c|c|c|c|c|}
\hline Glacier & Orientation & $\begin{array}{c}\text { Minimum height } \\
\mathrm{m}\end{array}$ & $\begin{array}{c}\text { Maximum height } \\
\mathrm{m}\end{array}$ & $\begin{array}{l}\text { Area } \\
\mathrm{km}^{2}\end{array}$ & $\begin{array}{c}\text { Maximum length } \\
\mathrm{km}\end{array}$ & $\begin{array}{c}\text { Maximum width } \\
\mathrm{m}\end{array}$ \\
\hline Kherseh dar & North & 3380 & 3740 & 0.3 & 1 & 600 \\
\hline Chal-mishan & Northeast & 3180 & 3770 & 0.6 & 1 & 680 \\
\hline Chal-kabud & Northeast & 3600 & 3850 & 0.7 & 1 & 800 \\
\hline Chal-boran & Northeast & 3200 & 3700 & 1 & 1.8 & 600 \\
\hline Chal-fialeh-sun & Northeast & 3460 & 3600 & 0.2 & 0.9 & 500 \\
\hline Shah-Takht & North & 3100 & 3370 & 0.3 & 1.7 & 450 \\
\hline Chal-piaro & North & 3270 & 3380 & 0.4 & 1.4 & 400 \\
\hline Chal-Homayun & Northeast & 2860 & 3360 & 0.4 & 1.2 & 500 \\
\hline Chal-az-Nader & Northeast & 2800 & 3500 & 0.3 & 1.3 & 450 \\
\hline Kul-Shakul & North & 2880 & 3650 & 0.6 & 2 & 700 \\
\hline
\end{tabular}




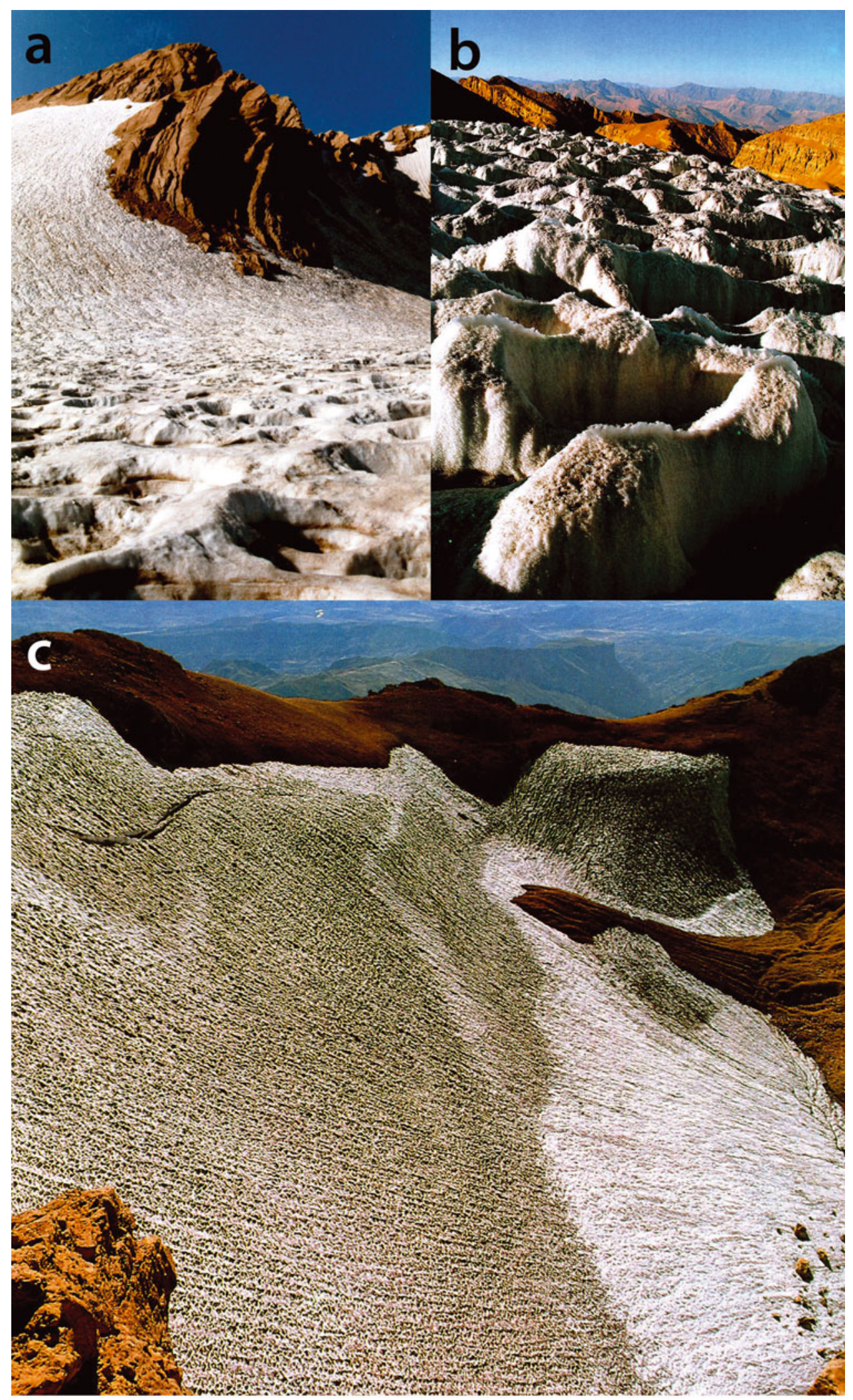

Fig. 14. Close-range photographs of Zardkuh region glaciers (October 1998): (a) sinkholes on the surface of Chal-mishan Glacier; (b) sinkholes on the surface of Zardkuh Southeastern Glacier; (c) Zardkuh Southeastern Glacier. (Photograph taken by F. Vaziri.)

Having performed the analysis on various data sources, such as aerial and satellite imagery, and also historic maps, output with a compatible format (ESRI shapefile) was imported into a GIS environment. The database of the glacier inventory includes topographic information and specific glaciological attributes, as well as the metadata. Different spatial data layers, including digital boundaries of glaciers, DEMs, drainage basin limits, basin areas and georeferenced satellite imagery of different time intervals, constitute our GIS database. Attribute data were included, in accordance with GLIMS standards. In order to guarantee sustainable utilization of these resources for a wide range of scientific and 
Table 6. Physical attributes of glaciers in the Zardkuh region

\begin{tabular}{|c|c|c|c|c|c|c|c|}
\hline & Glacier & Orientation & $\begin{array}{l}\text { Minimum height } \\
\text { m }\end{array}$ & $\begin{array}{l}\text { Maximum height } \\
\text { m }\end{array}$ & $\begin{array}{l}\text { Area } \\
\mathrm{km}^{2}\end{array}$ & $\begin{array}{l}\text { Maximum length } \\
\text { km }\end{array}$ & $\begin{array}{c}\text { Maximum width } \\
\mathrm{m}\end{array}$ \\
\hline \multirow{5}{*}{$\begin{array}{l}\text { Glaciers around Joft-zarde } \\
\text { and Shah-Shahidan } \\
\text { summits }\end{array}$} & Chal-mishan & North & 3000 & 3800 & 0.9 & 2 & 1000 \\
\hline & Joft-zarde & Northeast & 2900 & 3900 & 1.3 & 2 & 700 \\
\hline & Khersan & Northeast & 3620 & 4060 & 1.8 & 2.3 & 700 \\
\hline & Pursunan & Northeast & 3650 & 4000 & 0.4 & 1 & 400 \\
\hline & $\begin{array}{c}\text { Zardkuh } \\
\text { Southeastern Glacier }\end{array}$ & Noutheast & 3600 & 4100 & 0.6 & 1 & 400 \\
\hline \multirow{4}{*}{$\begin{array}{l}\text { Glaciers around Sirdan } \\
\text { summit }\end{array}$} & Kuhrang (1) & Northeast & 3300 & 3840 & 0.4 & 1 & 400 \\
\hline & Kuhrang (2) & Northeast & 3000 & 3720 & 0.5 & 1.6 & 300 \\
\hline & Kuhrang (3) & Northeast & 3090 & 3640 & 0.4 & 1.2 & 450 \\
\hline & Kuhrang (4) & Nnorth & 3400 & 3770 & 0.4 & 1.2 & 500 \\
\hline Haft-tanan (Iluk) Glacier & & Northeast & 3540 & 3800 & 0.4 & 1.2 & 300 \\
\hline
\end{tabular}

administrative applications, it is necessary to provide detailed standardized descriptions of the various datasets (Braun and others, 2001). In particular, these metadata records must comprise background information on data accuracy, and data sources should be compatible with a future data model for Iran glaciers (Braun and others, 2001). Hence, we created the metadata in the course of the work.

\section{CONCLUSION}

In this work we present the results of a first comprehensive inventory of Iran's glaciers. Five main glacier zones were identified and studied, using aerial and satellite imagery; related glacial attributes were extracted, with high accuracy, using different image-processing techniques. This work is significant; the first thorough study of Iran's glaciers using remote-sensing technology.

The glaciers are found in the higher elevations of the Alborz Mountains in the vicinity of Takhte-Soleiman region in the west, on Mount Damavand in the east, on the Sabalan Mountains in the northwest and on Zardkuh and Oshtorankuh Mountains in the Zagros mountain range in the southwest. Based on their geological structure, Iran's glaciers can be divided into two groups: (1) granite glaciers and (2) karstic glaciers. These two types of glaciers have different glacial features (e.g. the thickness of ice in karstic glaciers is less than that of granite glaciers). Moreover, special features, such as crevasses and moraines, are not found on karstic glaciers. The glaciers in the Takhte-Soleiman and Sabalan regions and around Damavand summit have the granite structure, whereas the Oshtorankuh and Zardkuh glaciers are karstic.

All the products from applying image-processing techniques on aerial and satellite imagery, including digital boundaries of glaciers, DEMs, drainage basin limits, basin areas and georeferenced satellite imagery, were incorporated into a GIS-based glacier inventory database.

A subject of ongoing research is to derive metric information on glacier flow using optical and synthetic aperture radar imagery. Future work will represent the results of surface displacements of Alamchal Glacier over a 2 year interval using high-resolution satellite imagery. We will use the results to update the Iran glacier database, providing more information about glacier dynamics and local climate change.

\section{ACKNOWLEDGEMENT}

We thank the K.N. Toosi University of Technology, Tehran, for financial support.

\section{REFERENCES}

Berthier, E. and 7 others. 2005. Surface motion of mountain glaciers derived from satellite optical imagery. Remote Sens. Environ., 95(1), 14-28.

Bobek, H. 1937. Die Rolle der Eiszeit in Nordwestiran. Z. Gletscherkd., 25, 130-183.

Braun, M., F. Rau and J.C. Simôes. 2001. A GIS-based glacier inventory for the Antarctic Peninsula and the South Shetland Islands - a first case study on King George Island. Geo-spatial Info. Sci., 4(2), 15-24.

Busk, D.L. 1933. Climbing and ski-ing in the Elburz Range, North Persia, 1931-2. Alpine J., 45(247), 334-341.

Desio, A. 1934. Appunti geografici e geologici sulla catena dello Zardeh Kuh in Persia. Memorie Geologiche e Geographiche di G. Dainelli, 4, 141-167.

Ferrigno, J.G. 1991. Glaciers of the Middle East and Africa. Glaciers of Iran. In Williams, R.S., Jr and J.G. Ferrigno, eds. Satellite image atlas of glaciers of the world. Denver, CO, United States Geological Survey, G31-G47. (USGS Professional Paper 1386G-2.)

Grunert, J., H.G. Carls and C. Preu. 1978. Rezente Vergletscherungsspuren in zentraliranischen Hochgebirgen. Eiszeitalter Ggw, 28, 148-166.

Harding, J.G.R. 1957. Cambridge Expedition, 1956, to the Elburz Mountains, Iran. Himalayan J., 20, 112-121.

Paul, F. 2003. The new Swiss glacier inventory 2000 - application of remote sensing and GIS. (PhD thesis, University of Zürich.)

Péguy, C.P. 1959. Les glaciers de l'Elbourz. Bull. Assoc. Géogr. Fr., 284-285, 44-49.

Rezaei, Y. 2003. Investigation on Khersan mountain glacier in Zardkuh Mountains: application of remote sensing and GIS. (MSc thesis, K.N. Toosi University of Technology.)

Schweizer, G. 1970. Der Kuh-E-Sabalan (Nordwestiran): Beiträge zür Gletscherkunde und Glacialgeomorphologie vorderasiatischer Hochgebirge. Tübinger Geogr. Stud., 34(3), 163-178.

Troll, C. 1973. Geoecology of the high-mountain regions of Eurasia. J. Ecol., 61(3), 937-938.

Trouvé, E. and 12 others. 2007. Combining airborne photographs and spaceborne SAR data to monitor temperate glaciers: potentials and limits. IEEE Trans. Geosci. Remote Sens., 45(4), 905-924.

Vaziri, F. 2003. Preliminary study of glaciers in Iran. Tehran, State Management and Planning Organization. 